\title{
DOSSIÊ: PATRIMÔNIO
}

\author{
Diana Farjalla Correia Lima' \\ Universidade Federal do Estado do Rio de Janeiro
}

\begin{abstract}
A Revista Museologia \& Interdisciplinaridade neste número temático dedicado ao Patrimônio apresenta oito profissionais - autores e organizadora da coletânea -- afinados com o perfil da publicação criada pelo Curso de Museologia, vinculada ao Grupo de Pesquisa Museologia, Patrimônio e Memória do Programa de Pós-Graduação em Ciência da Informação da Universidade de Brasília.A composição do grupo escolhido retrata pontos de conexão firmados nos entrelaces dos caminhos cotidianos que o espectro do conhecimento desenvolve no contexto da Museologia. E, em especial, pela graduação em Museologia: Bruno Brulon, Diana Farjalla Correia Lima, Elizabete de Castro Mendonça, Icléia Thiesen, Ivan Coelho de Sá, Luisa Maria Rocha; pela pós-graduação em Ciência da Informação;Alegria Benchimol, Diana, Icléia, Luisa,Valéria Gauz; em Memória Social: Diana, Priscila Cabral Almeida; pelo exercício docente: Bruno, Diana, Elizabete, Icléia, Ivan, Luisa (Museologia e Patrimônio, História); pela vivência nos espaços dos museus de Ciências e de História:Alegria, Luisa,Valéria.

Portanto, um elenco cujas experiências são a razão de estarem partilhando na Revista as facetas das questões patrimoniais no panorama museológico. Seus olhares dizem da multiplicidade das feições interpretativas e nominações que o assunto apresenta ao modo de um mosaico de cuidadosa elaboração. E no âmbito das perspectivas do Patrimônio integradas ao campo museológico, domínio detentor de aspectos da ordem do patrimônio musealizado e do patrimônio musealizável, e do duplo efeito da musealização ao efetivar a patrimonialização, os autores nas abordagens construídas compõem um painel da representação patrimonial cujos conteúdos ensejam estimulantes reflexões.
\end{abstract}

Assim, perpassando o conjunto conceitual e instrumental dado a patrimônio, patrimonialização, museologia, musealização nas interpretações emprestadas e nas discussões encetadas a presente edição faz-se composta pelas seguintes proposições:

Icléia Thiesen e Priscila Cabral Almeida em "Lugares de memória da ditadura e a patrimonialização da experiência política" focalizam a problemática que envolve a institucionalização de espaços vinculados a memória das lutas da resistência ao regime de exceção. A pesquisa no que concerne à reconstrução

I Museóloga (MHN-UFRJ), professora: curso de graduação em Museologia, UNIRIO, e Programa de Pós-Graduação em Museologia e Patrimônio UNIRIO/MAST, pesquisadora CNPq. 
da memória coletiva destaca o emblemático e ainda obscuro episódio nomeado Guerrilha do Araguaia (1972-1974), indica a relevância da justiça de transição como espaço e processo interdisciplinar conceitual e operacional para elucidação das ocorrências. $\bigcirc$ artigo vem a representar um aporte estratégico para apropriar, musealizar e patrimonializar os lugares de memória "dando publicidade aos fatos encobertos", até agora.

Bruno Brulon em "Patrimônio íntimo: a experiência do autêntico nas artes primeiras" relaciona a experiência do visitante de uma exposição museológica de material etnográfico à questão da atribuição de valor pelo museu a este tipo de coleção. E ao ser classificada como artes primeiras sob o prisma do valor estético alija do contexto a interpretação antropológica. Como exemplo da situação focaliza o Museu do quai Branly. Aponta a necessidade de rever os referenciais aplicados no âmbito da Museologia e do Patrimônio para analisar os processos de "autentificação" e valoração dos objetos de culturas 'estranhas' aos olhares etnocêntricos europeus e, para tanto, articula proposta baseada na "perspectiva axiológica para investigar a patrimonialização e a musealização como processos sociais".

Alegria Benchimol aborda "A musealização da coleção etnográfica do Museu Paraense Emílio Goeldi”. No largo período temporal da realização do processo museológico envolvendo a coleção, em especial representativa da região amazônica, dá a conhecer os aspectos conceituais e as ações que foram aplicados e desenvolvidos pelos especialistas responsáveis. Relaciona ao conceito de objeto etnográfico o de artefato, de mentefato e de documento. A pesquisa revela que as etapas da musealização se processam de forma interdependente, em modo complementar e definindo o "status do objeto como patrimônio".

Valeria Gauz em "O livro raro e antigo como patrimônio bibliográfico: aportes históricos e interdisciplinares" no quadro das tipologias e da polissemia patrimonial apresenta o aspecto singular detido pelos Livros Raros: mantêm o caráter original na patrimonialização, isto é, permanece livro com sua função de leitura, diferentemente de outras classes do patrimônio que sofrem ressignificações. $O$ contexto de construção do patrimônio bibliográfico é debatido e a pesquisa alerta para carências de investigações sobre o tema, "uma quase invisibilidade", situando que "Praticamente não existem grupos de pesquisa no país, integrantes do CNPq, que se dediquem especificamente ao livro raro e ao patrimônio bibliográfico na atualidade".

Elizabete de Castro Mendonça apresenta o "Programa Nacional de Patrimônio Imaterial e museu: apontamentos sobre as estratégias de articulações entre processos de patrimonialização e de musealização" e faz ver a Musealização atuando como instrumento de Patrimonialização no contexto de ação da esfera oficial, âmbito de planos de salvaguarda (2002-20I3) voltados às expressões culturais imateriais. A pesquisa toma como estudo de caso a proposta de criação do Museu do Samba (em andamento), transmutação do perfil do Centro Cultural Cartola: da titulação ao seu conteúdo de representação. $A$ análise busca identificar e questiona as condições conceituais e práticas que poderiam respaldar a mudança. Sua reflexão aponta as estratégias de articulação para patrimonializar e musealizar encaminhando reconhecer o papel dos museus ao modo de um equipamento cultural "no cenário das políticas públicas federais para bens imateriais". 
Luisa Maria Rocha vem expor e discutir em "Patrimônio meio ambiente e museologia de relações: reflexões sobre um patrimônio no devir" as dificuldades enfrentadas pelos museus com suas práticas atuais para atuar de modo ativo no tema da conservação de um meio ambiente que irá se perpetuar no futuro. E o patrimônio ambiental no seu senso coletivo merece ser encarado segundo valor de "patrimônio ético", articulando-se ambiência de relações entrecruzando questões de ordem política, econômica, social, cultural, infocomunicacional entre outras, expandindo conceitos tradicionais de preservação e patrimônio que redefinem o papel do museu na guarda e na gestão de "projeto de patrimônio" alicerçado "nas gerações futuras". No espaço da musealização desse patrimônio emergem a cidadania e direito ao meio ambiente construído no presente e voltado ao tempo vindouro, assumindo o museu o caráter social de território conceitual de adequação temática e de ação para "exposições, sensibilização, debates, mobilização e legitimação".

Ivan Coelho de Sá no artigo "Lygia Martins Costa: narrativa sobre suas contribuições à Museologia e ao Patrimônio" permite conhecer na conjugação patrimônio e museologia a trajetória de D. Lygia, "atualmente com quase I0I anos de idade", a atividade desempenhada peça primeira mulher museóloga a atuar no IPHAN (anos 50) ao lado de nomes emblemáticos da história da instituição. Sua vida profissional assinala ativa participação na identificação e classificação de acervos artísticos no Museu Nacional de Belas Artes e no IPHAN, na criação e efetivação de associações profissionais: Organização Nacional do ICOM (ONICOM); Associação Brasileira de Museologia (ABM), e na responsabilidade por exposições de grande vulto. Sobretudo, sua vida revela caráter pioneiro descortinando caminhos para os museólogos e permite acompanhar momentos da história da Museologia e do Patrimônio no Brasil.

Ao encerrar a breve introdução refletindo o conjunto dos artigos e na qualidade de coordenadora desta edição, eu convido os leitores a desfrutarem do prazer que tive ao ler cada um dos textos. As mãos hábeis dos autores irão conduzi-los para as interessantes vias que descortinam. 